\title{
Neologism and the Media in Contemporary Cameroon English; a Sociopragmatic Approach
}

\author{
Willie Mushing Tamfuh \\ Department of English, Faculty of Arts, Letters and Social Sciences, Adamawa Region, Ngaoundere, Cameroon
}

Email address:

mustamwill@yahoo.fr

\section{To cite this article:}

Willie Mushing Tamfuh. Neologism and the Media in Contemporary Cameroon English; a Sociopragmatic Approach. International Journal of Language and Linguistics. Vol. 8, No. 5, 2020, pp. 192-204. doi: 10.11648/j.ij11.20200805.12

Received: August 10, 2020; Accepted: September 3, 2020; Published: September 19, 2020

\begin{abstract}
Contemporary Cameroon English is a reflection of many decades of its historical, political, social and linguistic development. The aim of this investigation, as descriptive linguistics, is to observe what, how and why the common Cameroonian citizen creates, coins and form new words in English speech, collect and analyse this as naturally occurring sociolinguistic data, characteristic of contemporary Cameroon English speech. The objective is to highlight on the linguistic and cultural diversity of Cameroon as a leit motive to create and introduce new words into the vocabulary system, thus, enriching contemporary Cameroon English. Both quantitative and qualitative research was carried to obtain valid data typical of Cameroon society based on the sociolinguistic and ethnographic methods of inquiry and analyses using a combination of the critical discourse analysis, semantico-pragmatic and speech act theories. After the analysis, contemporary Cameroon English is enhanced through different linguistic techniques such as dialectal and cultural borrowing, self-explained compounds, neologisms, eponym, and inflections, among others, which is of great interest to English language learners and teachers of today. These linguistic techniques have enriched Cameroon English vocabulary as a variety of speech typical of Cameroon English.
\end{abstract}

Keywords: Neologism, Media, Contemporary English, Cameroon, Sociopragmatics

\section{Introduction}

Over several decades, many scholars have claimed that the art of invention is the sole propriety of scientific research in pure science, chemistry, physics, and not in arts, letters and social sciences. Everyone would agree with me that contemporary English speech is characterized by the tendency for speakers to create new words, borrow others or make new meaning from old words. The English language is the universal language used by millions of speakers. The observation is that pronunciation, grammar and vocabulary of the English language have undergone structural and semantic changes to the extent that the indigenization of Cameroon English is of particular interest to many linguists and sociolinguists. There is, however, a dynamic but unnoticed linguistic process exercised by erudite language users to enrich contemporary Cameroon English; that is, create new words or use old words with new meanings, and borrow from other co-existing languages to express new concepts and experiences characteristic of the Cameroon society. A study of neologism as a dynamic linguistic process and cultural diversity is worthy of scientific attention. The reason why different languages can lead people to create new words and carry out different actions is because language filters our perception, behaiour, and the way our experiences are categorized. Each one of us uses an infinite number of different speech sounds as communicative acts whenever we speak. One way to understand this is to examine the process of neologism or word formation, and how new words enter contemporary Cameroon English speech. This preoccupying linguistic phenomenon, par excellence, focuses on the recent and innovative research on languages nationally and internationally. Its empirical and theoretical aspects of is responsible for enacting new words into the everyday English speech of Cameroonians, providing new word forms and giving new meanings to the existing words in the language.

So intimate is the relationship between a language and the people who speak it that the two can scarcely be thought of apart. When people live in society and interact among themselves, language use becomes an indispensable 
instrument to express new ideas, beliefs, feelings and emotions. Language is, therefore. a tool employed by its users as a reflection of the social values, attitudes and culture of that society as well as a manifestation of social behavior. The invention of new words, how they are formed, their variation and the meanings attached to these are fundamental concepts that has enriched the vocabulary of a language. A sociolinguistic description of typical neologisms, used and accepted as mutually intelligible in the corpus on Cameroon contemporary English, requires an in-depth scientific investigation from a sociopragmatic perspective.

Located on the Gulf of Guinea, and considered the world's 54th largest country in Central Africa, the Republic of Cameroon, triangular in shape, has a population of approximately 25 million people (according to the 2007 national census) and occupies an area surface of about $475,442 \mathrm{~km}^{2}(183,570 \mathrm{sq}$. mi). It is bordered to the northeast by Chad, to the east by the Central African Republic, to the southeast by the Republic of the Congo, to the south by Gabon and Equatorial Guinea, and to the southwest by the Atlantic Ocean. Cameroon is endowed with a varied relief, flora and fauna, reminiscent of Africa in miniature, with its variety of culture and an amazing multilingual setting.

Curiously, after the German defeat in World War I, Cameroon was mandated to Britain and France on $28^{\text {th }}$ June, 1919. Under the League of Nations, French Cameroon achieved independence in 1960 as La Republic du Cameroun and the Southern Cameroons obtained theirs on the $1^{\text {st }}$ October 1961. As a result, these two territories with two different cultures attempted to unite as a United Republic. Thereafter, English and French were adopted as official languages in Cameroon with equal status and inscribed in the constitution ${ }^{1}$ and later in favour of a "United Republic of Cameroon. ${ }^{2}$ At the same time, the history of its indigenous population over hundreds of years has paved the way to its complex linguistic diversity and cultural identity, sources that have greatly impacted the development of new words into the Cameroon English speech. Despite this, it has equally been considered the source of an uncomfortable political union that has engendered the present seeds of political, social, linguistic and cultural discord.

Descriptive studies in the linguistic and cultural diversity of Cameroon are concern with the analysis of linguistic and social patterns, how new words develop and bring in new meanings continue to baffle scholars in different ways. The English language owes a great debt to William Shakespeare, who invented over 1700 of the common words found in English by forming new nouns from other nouns, changing nouns into verbs, combining noun with noun, transforming nouns to verbs, verbs to adverbs, connecting words never before used together, adding prefixes and suffixes to roots,

1. For more on this, see Art.1, par 3. of the Cameroon Constitution of 18 January 1996: The official languages of the Republic of Cameroon shall be English and French, both languages having the same status. The State shall guarantee the promotion of bilingualism throughout the country. It shall endeavour to protect and promote national languages.

2 For more, read Cameroon history and the famous Foumban Conference in 1961, and devising wholly original words. Few sociolinguists can refute the claim that the language we use affects and influences the hearers' thought, action and perception, and potential social behavior. Utterances are communicative acts produced as individual self-expression of social reality referred to as the instrument of society. The concept that language is a means of communicating thoughts, feelings and emotions is nowadays held to be a partial truth, more misleading than illuminating to readers.

According to Widdowson (1979) [1], 'parole' is the individual's use of language and 'langue' or usage the system guiding the way language operates including the norms, formal rules, structures, and limitations of language. A more enlightening concept, echoed in sociolinguistics, is that language is a form of social behaviour, interested in the underlying structures and claims that language is a manifestation of our thoughts and social behavior. This view, to an extent, is shared by linguistic philosophers, who claim that speech acts encapsulate a speaker's ideas and feelings. This shift in focus affected not only how we view the structure of language, but more so of its functions and how these might be learned as well. The observation is that there is a profuse upsurge of new words which have entered contemporary Cameroon English speech.

Due to controversial research using the critical discourse awareness, the imperialist expansion of the English language has been at the cost of local languages in many countries and Cameroon is not an exemption. Not surprisingly though, his views have been contested by those who regard the development of a wide variety of Englishes around the world as evidence that English no longer belongs to the English in England-nor even to the Americans. English today belongs to the various communities of speakers all over the world interested in its civilization and culture. When speakers of different languages interact closely, their languages influence each other, notably in word formation and vocabulary as speakers find themselves creating new words or borrowing from other languages. This dynamic feature has given rise to such varieties of English as British English, American English, Australian English, Nigerian English, Ghanaian English and similarly, the label Cameroonian English. The study of neologism is a multidisciplinary domain of interest relating to other fields of language as a social behavior intersecting with intercultural studies, language didactics, anthropology, sociology, literature, and psychology.

\section{The Linguistic Situation of Cameroon}

Considered a language paradise, Cameroon stands as the $8^{\text {th }}$ most linguistically diversified country in the world with a linguistic diversity index of 0.92 (according to UNESCO) of different language statuses. Note that Cameroon is equally the $6^{\text {th }}$ most ethnically diverse country in the world with over 250 ethnic groups. These figures, advanced by Breton and Fohtung's (1991:20) [2] study, is re-echoed by Wolf (2001) [3], Boum Ndongo-Semengue and Sadembouo (1999) [4]. Recent statistics in Ethnologue (2002) [5] credits Cameroon with roughly 300 tribes, and over 279 indigenous languages besides 
English, French and Cameroon Pidgin English (CPE) in coexistence, thus, presenting a peculiar and complex linguistic diversity unparalleled in Africa. All these languages are in constant contact with each other and used interchangeably by Cameroonians. While Mendo Ze (1990) [6], Bot Ba Njok (1966) [7] and Ngo Bitjocka (1992) [8] have studied problems inherent in Cameroon's bilingualism and the cohabitation of different languages in Cameroon, Biloa (1999) [9] has focused on Cameroon's official bilingualism. When speakers of different languages constantly come into close contact and interact with each other, they are influenced by each other either by creating, borrowing, codeswitching or coining new words from other the surrounding languages. So far, more research has been carried out on French and its vocabulary in Cameroon $^{3}$ and just a handful on the phonology and vocabulary of the English language. Chumbow (1996) [10] Mbangwana et al (2006) [11], and Mushing (2007) [12] have examined aspects of language, literature and cultural identity. Though both official languages ought to enjoy equal status as stipulated by the constitution, French has a de facto dominance over English in different areas of national life notably; politics, social, administrative, military, education and the media. It is no exaggeration that the use of French prevails in all domains in Cameroon with over $60 \%$ of the population being Francophones. Based on the demographic reality, English and French are used interchangeable in both formal and informal situations as in the senate, parliament, churches, public offices, conversations, speeches, markets, on radio, TV programmes, music, films, literary works, etc. However, a popular variety of substandard French is commonly used and acceptable in informal contexts among heterogeneous ethnic groups, especially in urban and rural areas, and between the anglophones, francophones, and fulfuldophones.

Since 2010 with the advent of democracy, Cameroon has witnessed a number of political and social upheavals characterized by Boko Haram terrorist insurgence, several contested election processes, the Northwest and Southwest anglophone secessionist crises, tribal conflicts, social injustice, poor governance, moral decadence, corruption scandals, insecurity, violence, human rights abuses, press liberty and the present alarming Corona Virus Disease (COVID-19) pandemic, all of which constitute serious challenges that have affected the political, social and cultural life of Cameroon as an emerging society. These events and situations, in themselves, usher in new concepts and alternate perceptions, thereby introducing new vocabulary into the English used. Speakers find themselves creating new words to express these new ideas and feelings, borrow utterances and words from familiar surrounding languages to describe the current affairs affecting their lives. Such events and

3. For more on this, see The 'Inventaire des Particularités Lexicales du Français en Afrique - Cameroun, (IFACAM) team, since the late 70s, headed by Jean Tabi Manga working on the lexical peculiarities of the French language in Cameroon. Others include Joseph Mendo Ze (1990), Ngo Bitjocka (1992), etc.

4. See Francis Mbassi-Manga (1973), Sammy Beban Chumbow, (1996: 5), Edmond Biloa (1999): Paul Mbangwana (1987, 1989, 2002), Paul Mbangwana, K Mpoche, \& M. Mbuh (2006), Willie Mushing Tamfuh (1989, 2007). experiences provide vast and appropriate opportunities and available resources from which the speaker draws inspiration to borrow, create or develop new words. The use of native and indigenized words to describe new concepts has been outstanding. When people think in terms of tribal, social or national affiliations, they speak and behave in like manner. Though some old words may carry new meanings, the birth of new ones come in to enrich the linguistic repertoire and the vocabulary system of English in Cameroon. Naturally, speakers would borrow words, coin or adopt new ones as a way to clearly express new ideas that are intimately associated with an object or concept that acceptance of the thing involves acceptance of the word. Over the years, even though language scholars have shown particular interest in them, they have also entertained fears that the complex multilingual situation of Cameroon, though this complexity is a mark of linguistic diversity, it is also a potential source of linguistic controversy and cultural conflict.

Chomsky's (1957) [13] major contribution to the study of language use has been to give it a scientific approach. He notes that the scientific study of language use attempts to understand the character of mental processes i.e. "language is a mirror of mind." As we come to know that there is a universal basis in the mind that incorporates the basic principles and we set values to these principles based on the data we get by exposure to an unorganized and random set of utterances via interaction with other people. By examining native speakers' underlying knowledge, it is easier to get a better understanding of how the mind works: language is a window into the mind. Language use is not merely an exercise of any speech habit or skill display as many would think, the use of language is creative i.e., it constantly involves the production and interpretation of new forms and new experiences to the language user in the history of the language and the people.

The study of new words, the way they are formed and used with different shades of meaning dates as far back as the history of the English language. The word understand is derived from the fact that the prefix 'under,' once meant 'among'. Thus, 'I understand' these things' may have meant, at first, 'I stand among these things'. Here, the word 'understand' in old English the same meaning as in Middle or Modern English. Note, however, that being a compound lexeme of 'under and 'stand' might be different from the compound of 'stand' and 'under.' The structural units do not imply anything as to its meaning. Chomsky's (1957) [13] theory posits that language consists of both deep structures and surface structures: Outward-facing surface structures relate phonetic rules into sound, while inward-facing deep structures relate words to conceptual meaning. For instance, he describes two levels of language; form and meaning; a surface structure has a surface meaning, and a deep structure deals with a deep meaning. He believes that the word 'understand' equally means 'to look at that is standing or visible,' but, to see that which is 'under' or the hidden sense of the word as ghost town, lockdown, country-Sunday, comeno-go. A ghost town is not a town full of ghosts nor come-nogo, that which comes but cannot go. To 'understand' an 
utterance therefore is to look at what it refers to as the 'deep' meaning of the utterance, not from its 'surface structure. This implies that the real meaning of a word lies at a deeper level of interpretation. How do old words take on new meanings and how do different new words and expressions take on denotative or connotative meanings in Cameroon English speech? Such new words such as ghost town, lockdown, country-Sunday, come-no-go, bamenda, Bamis, anglo-bami, moto-taximan, bendskiner and scores of other expressions are commonly acceptable as mutually intelligible in the everyday English speech in Cameroon as they express new concepts and reality more vividly. In other instances, old words with new meanings have sprung up from different events in Cameroon and carry varying shades of meanings.

\section{Research Statement}

One may be interested in language use for many different reasons, and from many different points of view. Chomsky (2012) [14] had these central questions in his mind which dominated his interest: (1) What is it that we know when we speak a language? (2) How is this knowledge acquired? Answers to these questions would have been something like this: (1) A language is a certain system of habits manifestation and skills display; to know a language is to have and demonstrate a mastery of these skills. (2) Knowledge of language and its use is demonstrated by such mechanisms as blending, coinage, derivatives, eponymy, compounding, association, and the practice in exercising these skills, etc.

The point is that Cameroon English vocabulary is versatile; hence a word can take on a variety of meanings depending on its context of use. On a stronger note, speakers may employ one word to express an idea or an utterance to express a divergent of ideas. The study of the expressions ghost town, lockdown, country-Sunday, come-no-go, bamenda, Bamis, anglo-bami, la ruepublique, hooligan Tontinards, antiSardinard, waajo, mouton, anglo, apprentis sorciers, and une proximité sociologique can be quite complex and give room for a multiplicity of interpretations. The problem is that despite the linguistic and ethnic diversity, this rich linguistic situation remains both a source of enrichment of its grammatical and vocabulary system as well as a source of social and political conflict.

To what extent is the ability to create new words a contributing factor to the upsurge of new expressions including tribalism and hate discourse in Cameroon? To what extent is the media responsible for creating and propagating new words in contemporary Cameroon English? These questions and others constitute the bases of the present inquiry. The proceeding paragraphs shall examine some of the different linguistic processes by which Cameroon English is structurally and pragmatically enriched.

This investigation sets out to observe naturally spontaneous speech used by Cameroonians in real instances, collect and examine typical samples of neologisms in order to analyse their structure and significance as meaningful units characteristic of contemporary Cameroon English. The concern of this investigation is with the speaker's linguistic competence and ability to form new words as the manifestation of concrete measurable reality as well as an abstraction of his social behavior within the Cameroon society. The study is diachronic, data-oriented and descriptive in nature considering the importance of studying new words, their forms and the varying meanings. From a pragmatic perspective, there is an intrinsic relationship between linguistics, sociology and psychology in understanding the impact of language use and variation in contemporary Cameroon English.

At the end of this investigation, readers would be able to understand the typical processes involved in word formation in a living language as Cameroon English, and use these linguistic abilities and processes to coin new words in their language. It will create greater awareness on speech forms characteristic of contemporary Cameroon English. It is worth noting that a sociopragmatic description of morpho-lexicosemantic processes of word formation is relevant in enriching the vocabulary of a language, giving these words new life and demonstrating the arbitrariness and flexibility of a language in the hands of one who masters its rules. Its object is not to lay down fast and strict rules about how people should speak or write the language as traditional grammarians would. Sociologists, like ethnomethologists are concerned with the description of social and linguistic behavior as it actually is. A critical analysis of Cameroon English demonstrates that language use is intrinsically related to society on the assumption that they are perfectly satisfactory for the communicative purposes of the people who speak it. Descriptive linguists are primarily concerned with finding out what people actually do in terms of their linguistic behavior. In the case of speech, we have to say that it is not naturally divided up into words and sentences, but rather into utterances, that is, streams of speech marked off from other utterances by silence. It may so happen that some utterances do coincide with certain thoughts, e.g., lockdown, country-Sunday, anglo, yet others are totally strange as in maurika, others with phrases or speech-stream les apprentis sorciers, correlating with the idea that an individual's thoughts and actions are determined by the language or languages that the individual speaks.

\section{Hypothesis}

The issue is that native speakers of a language, irrespective and their particular idiolects, do have a vast amount of shared linguistic knowledge, including tacit awareness of the speaking norms and rules, that regulates the way the language is used. Native people vary from each other in the way they use a particular language, in what circumstances, to who and where? Knowledge of social status, age, gender are very important.

Over several years, the dynamic character of contemporary Cameroon English vocabulary, like all living languages, has been subject to constant grammatical and lexical changes. Thirty years ago, for example, it was impossible to talk of 
mixing both English and French as in viens on go, or from Latin 'my pater, my mater is in the house' and considered acceptable among the youths in Cameroon as 'camfranglais,' a neologism derived as a result of compounding 'Cameroon', 'Francais' and 'anglais', and even Latin, typical of modern Cameroon English speech. Holmes (2001) [15] cites Pennycook's (2016) [16] controversial research which emphasizes on critical awareness of new forms arguing that the imperialist expansion of the English language has been at the cost of local languages in many countries. Not surprisingly, his views have been contested by those who regard the development of a wide variety of Englishes around the world as evidence that English no longer belongs to the English-nor even to the Americans. Neologism constitutes the act by which new words are formed and enter into the vocabulary system is a common and dynamic process of all living languages including contemporary Cameroon English.

The principle that languages and dialects are important as they are for the purposes of description holds that all languages have the potential to develop for particular purposes not hitherto considered important by their speakers, nor perceived as such by users, but it is certainly true that no language has all the vocabulary needed for communication, nor all available structures to deal with everything in human experience as a whole. Languages are closely tied to the speakers and the cultures in which they are spoken, and the process of linguistic modification and change, which is essentially the product of cultural change, may take many years. If language is the medium by which people communicate their ideas, feelings and emotions, then there is a very close relationship between language, the people and culture. Drawing from studies of the Amerindian primitive tribes, Whorf, 1940 cited in Carroll (2012) [17] found out that native speakers of Hopi (a North American Indian language) perceive reality differently from native speakers of English because they use different languages. Speakers of Hopi must choose between two words in their language for what English speakers call water. They refer to it as pathe if it is freely running as a river, and as keyi if it is confined, as in a bottle or glass. In as much as the Hopi perceives objects differently from the English, from the examples above, so too does the Englishman and the Wimbum perceive the same things differently and different things in like manner. Previous studies in Limbum demonstrate that where the English language contains separate lexical terms for finger and toe, the Wimbum talks of mtuu mbo and mtuu mkuu respectively. But, the Englishman sees the 'finger' and 'toe' as distinct parts of the human anatomy, while the Wimbum, describes them as fingers on the hands' and fingers on the foot not toes, for Limbum does not separate these in like manner. The Wimbum use rho for stream water and mdip, water if it is confined for drinking. Both terms refer to mdip, water. However, if the stream is clean, it is referred to as mdip rara or 'clean water and mdip nno as drinking water (Mushing, 2007) [12]. Thus, the differences in culture are probably more startling when reflected in different languages, as Hopi/English, Limbum/English. Although the vocabulary system of our language serves us to communicate, its efficiency does not depend upon the perfect use and reception of every single element of speech. The point is that we see and hear, and otherwise experience life very largely as we do as a result of the language habits we have developed in our community which predisposes the user with certain choices of interpretation. The examples cited above, from different speech communities, led anthropologists and sociolinguists to postulate that language use determines a person's thought and that his linguistic categories limit and determine his cognitive categorisations. The concept that language use determines a person's thought and his linguistic categories was first advanced by anthropologists Edward Sapir in 1929 and subsequently developed by Benjamin Whorf (Carroll, 2012), [17] who observed that the structure of a language determines a native speaker's perception and categorization of experiences. The Sapir-Whorf hypothesis claims that people from different cultures think differently because of differences in their languages. Some sociolinguists accept such a strong claim, but most of them consider the weaker claim that language influences perceptions, thought, and, at least potentially, behavior. Also known as the Sapir-Whorf hypothesis, this linguistic relativism is a principle, which claims that the structure of a society affects its speakers' world view or cognition, and thus, a person's perception is relative to the language he uses.

\section{Scope of Study}

Many linguists have described phonetics, phonology, morphology, syntax of the English language as isolated units of language structures. Our scope of study is the semantic and pragmatic description of neologisms in conversation speech within Cameroon with particular attention to meaning and different senses in contemporary English. These utterances, considered as communicative acts, constitute the smallest units of meaning in speech based on the speaker's beliefs and intended meaning.

The Ethnography of Communication presents the terms and concepts which are essential for discussing and analyzing how and why language is used and how its use varies in different cultures. While practitioners of Critical Discourse Analysis might want to amend this, the set of concerns sketched here well describes the field of the ethnography of communication Saville-Troike (2003) [18] and CDA. The only comment I would make, a comment crucial for many practitioners of CDA, is to insist that these phenomena are to be found in the most unremarkable and everyday social encounters as conversational texts - as well as other texts. This scope, and the overtly political agenda, serves to set CDA off on the one hand from other kinds of discourse analysis, and from textlinguistics (as well as from pragmatics and sociolinguistics or sociopragmatics) on the other.

The scope of sociopragmatics examines these communicative acts by considering the underlying norms and native speaker intuitions of how speaker and hearer make out meaning as reflected in the (appropriate) realization of 
speech acts, including the description of different word formation processes as re-lexicalization, lexical codeswitching, neologism, self-explaining compounds, borrowings, prefixation and suffixation, eponyms, and acronyms as typical techniques speakers use to enrich Cameroon English, which, for quite a long time, has received little or no scientific attention.

Before proceeding any further, it is important to examine some of the basic concepts used in this investigation notably; Neologism, media, discourse, Contemporary English and sociopragmatics.

The term 'neologism' has been defined as the art of coining a new word, utterance or expression, or a new use of old words A neologism, from Greek véo- néo-, "new" and lógos, "speech, utterance", is a relatively recent term, word, or phrase used by speakers of a language, and may be in the process of entering common use, but that has not yet been fully accepted into the mainstream language. For example, the word 'camfranglais', is formed from a combination of Cameroon French- Anglais (English) forms as well as the word webinar, which is a combination of both 'web' and 'seminar' to coin 'webinar' for a seminar on the web or the Internet.

The term 'media' is used here to refer to the different means and institutions in charge of collecting, diffusing and transmission of information. A 'medium' serves as an intermediary with the aim to inform, educate, entertain and sensitise the population on daily happenings. It influences and changes the listener or reader's view and perception of the world.

The term 'Contemporary' is used to signify that which belongs to and is characteristic of the present circumstances and current ideas of the present times, characteristics of modern day. It is considered the product of centuries of development. As long as words are in actual use, they are in a constant state of change in form and meaning. In the same way a human being grows, so too each individual is constantly and quite unconsciously introducing slight changes in his life so is his speech. In contrast to Old English (O. E.) and Middle English (M. E.) periods, contemporary Cameroon English corresponds to the period of time between the modern English around 2000 till date. In this sense, it circumscribes to the variety of English speech frequently used, acceptable and understood as mutually intelligible in the present day Cameroon society.

In this study, the term 'pragmatics,' refers to the subfield of linguistics and semiotics that study different ways in which context contributes to meaning. It is a philosophical doctrine concerned with practical matters as the object and consequences of studying meaning and value in what people say in real life situations. Pragmatics covers the broad range of speech acts performed by using words and sentences. Pragmatics examines the practical use of linguistic signs, words and utterances in their actual situations as speech acts capable of performing an action. Thus, the concept of 'sociopragmatics' deals with the study of social factors that govern our choice of language in social interaction and the significant effects of these language choices on other members of the society.

\section{The Cameroon Media}

The growth of the multi-media in Cameroon, from the audio, print, audio-visual to digital communication, has experienced great developments in recent times. The Cameroon media, including the numerous radio stations, ${ }^{5}$ television channels, ${ }^{6}$ advertisement boards, movies, documentaries, the Internet, newspapers, ${ }^{7}$ magazines, arts, music, and the social media, ${ }^{8}$ are different organs through which people express their ideas, feelings and emotions publicly. Although information on the social media suffers incredibility, they continue to greatly influence contemporary Cameroon English with new words being created, as many old words taking on new meanings. Known as the fourth power, the multi-media continues to greatly influence the use, spread and normalisation of new words in different areas of social life in Cameroon. The media has the power to manipulate public opinion and change people's views. In addition, it can reach a large audience all around the world in a very short period of time. In the course of their investigation, journalists and other media practitioners punch in these words and expressions into the consciousness of its listeners. It is commonplace to hear these new words when one follows heated debates on different media on such topical issues in Cameroon as tribalism; Beti, Bami, duala, Nanga, etc, the NOSO Anglophone crises; separatists, ambaboys, General fire, field marshal, General peaceplant, General Death, the Ngarbuh massacre, the 'Survivre Cameroun Survival Initiative' affair, presidential, legislative and municipal elections, Alteration at the summit of the State, COVID-19, the Wazizi affair, Human Rights abuse, Boko Haram terrorism, hate speech; such as autochthons, come-nogo, gadamayo, Gouachie, etc., corruption; gombo, kola, tchoko, aroser etc. To compile his report, the journalist selects, forms, creates and introduces new words into the vocabulary system of the language. Press freedom has greatly influenced the insertion of new words into Cameroon English to reinforce and enrich its vocabulary system of Cameroon English with different concepts. For sometimes now, some old words continue to take on new meanings that enrich the English vocabulary. The word 'anglo,' for example, has taken on a political tone, synonymous to secessionists, armed militia, ambaboys, and terrorists to signify 'unpatriotic enemies of the

\footnotetext{
5. Today, unlike 20 years ago, countless radio stations operate in Cameroon notably; CRTV-Radio, FM 102.5 Adamawa, Cameroon Radio-Television (CRTV), Yaoundé FM 101, Mount Cameroon FM, Poala FM.; Abakwa FM, Radio Véritas, Satellite FM, Magic FM, Radio Sweet FM, just to cite a few.

6. Some major television channels are Cameroon Radio-Television (CRTV), CRTV sports, Equinox TV, Canal 2 International, Canal 2 Movies, LMTV, Vision $4 \mathrm{TV}, \mathrm{STV}, \mathrm{DBS}$ TV, InfoTV, etc.

7. Press liberty in Cameroon has witnessed the upsurge of a plethora of newspapers including; Cameroon Tribune, Défis Actuels, Eco Matin, Emergence, Essingan, Génération Libre, Info Matin, Jeune Afrique, La Météo, La Nouvelle, La République, L'Anecdote, L'Avenir, Le Financier d'Afrique, Le Jour, L'Oeil du Sahel, Mutations, The Guardian Post, The SUN, The Post, etc.

8. Some social media include Opera News, instagram, facebook, Twitters, messenger, youtube, whatsapp, Cameroonmagazine.com., Cameroonline.org, Editem opera news, lebledparle.com., actucameroon.com, camer.be, cameroonweb.com.
} 
nation'. Today, it is common place to learn that, General peaceplant, General Death, General Obi, etc., tend to describe the caliber, grade and function of specific persons referred to as 'generals' within the specific context of Anglophone crises. In a similar way are utterances as I am Florence Ayafor, Black live matters, I am George Floyd, I am Ngarbuh, I am Samuel Wazizi have become important messages speakers use to denounce social injustice and human rights abuse.

\section{Methodological Concerns}

Studies in ethnomethodology have inspired a wide range of important theoretical and empirical work in the social sciences and linguistic theories with focus on the way native speakers use language in everyday life and their social behaviour. Hilbert (1992) [19], Ritzer (2011) [20] and Garfinkel (2017) [21], have described various scientific methods for collecting adequate ethnographic data and analysing them based on the phenomenological reconstruction of Max Weber's verstehen sociology. The corpus for the present analysis is made of recordings of oral productions and published works collected as typical sample expressions of the variety of English produced by both English and French-speaking Cameroonians, many of who equally speak and understand Cameroon Pidgin English and use different Cameroon dialects. Authentic data quantitative and qualitative data was obtained from informants of both sexes, and from all walks of life including; researchers, medical practitioners, educated people, members of parliament, senators, legal minds, the military, traditional rulers, students, opinion leaders, journalists, etc., were consulted as reliable sources. These utterances occur in real instances of casual conversations, interviews, radio and TV debates, news broadcast, documents, books, postages on social media, newspapers and magazines etc. Besides the recorded speeches, a total of over 200 questionnaires were administered to the informants, collected and analysed. However, the speech of children below the age of 10 and that of foreigners were excluded from data collection.

Over 130 words and expressions were collected as recorded and written productions from different speakers of English, French, Cameroon Pidgin English, Camfranglais, and indigenous languages with particular attention to new words and expressions typical in Cameroonian society. Over $40 \%$ of the data is obtained in the English language, $45 \%$ from French, while 5\% is derived from Cameroon Pidgin English and $15 \%$ of these words and utterances are borrowed from other local languages. In many instances, where their speech was recorded, the speakers were unaware that their speech would be subjected to scientific analysis. To them, they were just expressing their ideas and speaking out their mind, pushing them to express their opinion on various sensitive subjects.

Garfinkel (2017) [20] considers ethnomethodology a distinct approach to sociological inquiry that painstakingly makes use of various techniques to observe the way language is used by members of any given speech community. They further lay down solid methods and principles to observe their verbal and social behaviour in face-face interpersonal conversations as social reality. The ethnography of speaking approach which studies naturally occurring speech events as conversational behaviour aims at understanding and accounting for what is said and how people behave in real social interaction with particular focus on the way participants in conversations constantly produce, negotiate and manage norms of speaking in everyday social life. Chomsky (2012) [14] argued that behaviorism, the dominant approach to language at the time, was no longer tenable. Behaviorism, according to Skinner (1957) [22], is a theory of learning which states that all behaviour are learned during social interaction with the environment through a process called operant conditioning. Thus, behavior is a response to environmental stimuli, a position less extreme than that of Watson (1913) in Todd and Morris (1995) [23]. Skinner believes that we do have such a thing as a mind, but that it is simply more productive to study observable behavior rather than internal mental events. What happens in conversational discourse cannot be ignored and linguistic analysts must account for these social facts.

While Skinner (1957) [22] focused on the language people were observed using, Chomsky (1957) [13] was interested in the underlying structure of language. This shift in focus affects not only how we view the structure of language, but how it might be learned as well; the data used to test these hypotheses are native speakers' intuitions on the grammatical and ungrammatical nature of the sentences of their language: What we study is what people implicitly know about their language and what they say. We do not study whether words and sentences abide by the 'rules' of grammar, but whether grammatical and ungrammatical sentences can be explained with the hypotheses we make. By examining native speakers' underlying knowledge, we get a better understanding of how the mind works and how language is a window into the mind.

Different methods of investigation requires concentration on observable behavior and the desire to investigate matters in which so much is not directly observable proved useful, is quite helpful in laying a solid foundation for a new type of study, sociopragmatics, capable of explaining how words, when formed, take on specific meaning in a given society. The analysis has concentrated on different aspects of 'spoken interaction', gathered in a variety of ways: from the employment of direct and indirect observation, to the use of naturalistic data collection methods, and production questionnaires, aimed at eliciting instances of spoken and written data. Grice's (1975: 26-30) [24] conversational implicatures and social interactionism are useful theoretical frames to understand language use as social behavior relevant in philosophy, enthnolinguistics, psycholinguistics and anthropology.

While ethnomethodology is often seen as far removed from mainstream sociology, descriptive linguistics continue to be interested in describing language use and change in the phenomenon of neologism as essential and influential in any developing society. 


\section{Theoretical Framework}

Different sociological theories attempt to explain how dynamic societies are organized, change and survive over time. Most of these analyses include the study of human utterances and their pragmatic meanings. Even though semantics deals with the relationship between linguistic expressions and their meaning, it does not only concentrate on how words express deep cultural meaning, nor the processes by which these words, phrases and sentences cohere together meaningfully in language.

According to the Sapir-Whorf hypothesis [17] is the theory that an individual's thoughts and actions are determined by the language or languages that individual speaks. The theory, developed by Edward Sapir and Benjamin Lee Whorf, states that the structure of a language determines and greatly influences the modes of thought and behavior characteristic of the culture in which it is spoken. Sapir-Whorf claims that the structure of the language one habitually speaks influences the manner in which one thinks and behaves. Both were fascinated by both psychological and cultural aspects of language functioning. This concerns exclusively linguistic research, which constituted the bulk of their work, and remained the body of their anthropological research.

Studying language functions as communicative acts from various perspectives, the speech act theory was first introduced in language analysis by Austin (1962) [25] and further developed by Searle, both philosophical linguists interested in what speakers do with language acts as presuppositions and their implicatures. We are attuned in everyday conversation not primarily to the sentences we utter to one another, but to the speech acts that those utterances are used to perform: requests, warnings, invitations, promises, apologies, predictions, and the like. Such acts are staples of communicative life, but only became a topic of sustained investigation, at least in the English-speaking world, in the middle of the Twentieth Century. It is in this light that Austin (1962) [24] attempts to describe language use in terms of studying "how to do things with words", today refined to "how people do things with words." Grice's (1975) [23] work on meaning has influenced the philosophical study of semantics. $\mathrm{He}$ is known for his theory of implicature. "Implicature" he asserts, denotes either (i) the act of meaning or implying one thing by saying something else, or (ii) the object of that act. The concept of 'act' refers to the directly observable action performed in the instance of speech in an event as the intended and interpreted meaning of behavior. Implicatures can be determined by sentence meaning or by conversational context, and can be conventional (in different senses) or unconventional. His aim has been to understand "speaker's meaning"-what someone means by using a specific utteranceas well as that which arises from "sentence meaning"- the literal (form) meaning of an utterance. Grice proposed that many aspects of a "speaker's meaning" result from the assumption that the participants in a conversation have a perfect knowledge of the language and are cooperating in order to reach mutual goals - or at least pretend to do so.

To understand its significance, it is important to consider particular sets of beliefs and experiences in the real world.
The pragmatic theory emphases on analyzing utterances from their context of use by providing a platform that establishes an intricate relationship between what people say, their perception of reality and the way meaning is derived from these elements. The fact is that an individual's thoughts and actions are determined by the language or languages he speaks.

Pragmatics is a relatively new discipline whose nature of inquiry intersects with that of a number of other social sciences as linguistics (applied linguistics, (critical) discourse analysis, semantics, sociolinguistics), sociology, psychology and anthropology. Pragmatics does not have a methodology of its own, but draws upon the methodology employed in other social sciences in linguistics, anthropology and sociology, for example. As the field of pragmatics is quite broad, it covers a variety of strands, from the study of (contextualized) sentence meaning to the study of meaning in interaction, and the way in which data are collected and analysed depends on the pragmatic perspective adopted by the researcher, as well as on the object of study.

Therefore, sociopragmatics as an empirical approach describes speech as social reality, i.e., what is said and what is meant and deals with the meaning of an utterance by considering its component parts from the whole context as a unit of analysis in which it is used within Cameroon. The fact is that the 'real world' is, to a large extent, unconsciously built up of constituent parts that can only be understood when decomposed as a part of the whole. In this case, the utterances under study are communicative units of meaning restricted within the Cameroon speech community.

\section{Sociopragmatic Analysis}

Leech (1983:10) [26] describes 'sociopragmatics' as the ways in which pragmatic meanings reflect 'specific local" conditions on language use', a sub-field of pragmatics that he distinguished from the study of more 'general' pragmatic meaning. Sociopragmatic analysis deals with the aspect of language use that relates to everyday social practices such as conversations, and more particularly, 'how communication of pragmatic meaning involves speakers' presentation of their identities.' Pragmatic competence requires speakers to use language appropriately and effectively in a particular context.

Thus, the concept of sociopragmatics involves the use of a set of both linguistic and sociological techniques for exploring underlying motives of what people say and what is meant to understand language use as a form of social behavior. To analyse performative acts is to understand the various forms of behaviour and how speakers create things with words. Note that common expressions such as alhaji, Hadja, marabout as well as waajo, from fufouldophone, for instance, are now being used all over Cameroon to designate people from the northern parts of Cameroon. In using the expressions waajo, gadamayo, mouton, Anglo, Sardinard, or tontinard, the speaker demonstrates his underlying ethnic prejudice and antagonistic motives that cannot be understood by anyone not versed with the political and social situation in Cameroon. However, in making any utterance, the speaker 
provides the listener (s) with certain cues for easy comprehension. The utterance, bamenda, for example, is a general term for people of the northwest region of Cameroon. A bamendaman is someone from the western grassfield region, and today, it is used for all the members of the Anglophone minority community in Cameroon. To refer to a group of people as mouton is outrageous in the same way as anglophone. Above all, calling someone a mouton breeds hatred in the same way as come-no-go which is a negative and denigrating image of the person implying that the person is a foreigner in his own country. The word mouton is considered an insult to a muslim faithful, while waajo is a diminutive and derogatory term for a young foulbe girl. Similarly, to call someone a bamendaman, is synonymous to someone who likes to criticize and oppose things. Words as Gouachie, and Ngarbuh, have entered contemporary English speech are reminiscent of disaster landslide and the killing of 15 villagers respectively, and a result of controversial and divergent reports on human rights abuse as expressions that bring sad memories and despair to people from these ethnic groups. A speaker, describing such circumstances and of necessity under pressure, need not search too far for the right words that can vividly describe the situation using the names of the villages which are familiar to listeners. He tends to borrow from the dialects as closest language at his disposal, relexify or create a new word as the case may be. In the preceding lines, we shall describe the different techniques used by Cameroonians to form different words.

\subsection{Borrowing}

The most common technique used by many speakers to bring in new words into Cameroon English vocabulary is that of borrowing or loaning. Borrowing is a deliberate, systematic and collective process that occurs in living languages. Over $80 \%$ of the words collected as corpus are loanwords borrowed from French, English, Cameroon Pidgin English and the indigenous languages. The word Tontinards, for example, is derived from 'tontine' or a meeting in a general sense, but in the context of the sentence; 'Tant que les hooligans Tontinards ne feront pas de la politique civilisée, je ne les lâcherai pas!!!, the speaker establishes a relationship between the Tontinards and hooligans. A hooligan describes a cruel, heartless and brutal fellow, one who is aggressive and ready to fight. The expression is reminiscent of a recent incident in 2019 when a group of Cameroonians of the diaspora, to demonstrate their anger against the existing regime, attacked the Cameroon embassies in Paris, Berlin and organized a series of protest marches. In a harsh tone, he uses the word hooligan as an attempt to discredit the wrong deeds undertaken by 'hooligans unable to do civilized politics. Note that these loan words express old ideas in new ways but are intimately associated with the current political situation in Cameroon. Here, the suffix '-ards', borrowed from English is attached to the free morpheme Tontine (a meeting), a noun to form a new word Tontinards with new meaning (people who meet together) and similar to Sardinards, and Brigarde Anti Sardinard (BAS). The words Sardinards and tontinards, introduced into Cameroon English speech. The expression
Tontinards, for example, can be traced from the English word tontine, describing an annuity financial scheme whereby members participate, play money and share certain benefits, and on the death of a member, his or her benefits are redistributed among the remaining participants. It runs for a fixed period of time as a life insurance. Belonging to this scheme is a common practice used in many speech communities in Cameroon to save money before the creation of banks. This familiar word has today taken a new political implication that has divided Cameroonians into politico-tribal entities. The meaning of these words is closely associated with the speaker's experiences of his immediate environment and culture as context. Borrowing is a situation in which the speaker appropriates of other existing forms and ideas by retaining the original pronunciation of the word with certain deep-seated cultural patterns, which give it a new meaning. Note that the meaning of Tontine is derived from English and used to describe a deep-rooted concept of self-help association typical of members of a particular social, ethnic or tribal group. In Bantu tradition, social life is communal and people live together in communities organized into different social or cultural groups, which in Mbumland are referred to as ngwaah and commonly called in Pidgin English njangi. Note that this gathering is principally based on tribal and ethnic sentiments with the objective to invest money for financial empowerment in order to realize future projects.

The word sardinard, for example, is also appropriated from different foreign language forms; French Sardine; Spanish Sardina; Italian sardine; Latin sardina; all of which are derived from the name given to the island of Sardinia, Ancient Greek (Sardela), with plenty colonies of the deep orange-red variety of the chalcedony fish are found. Note that French, Spanish, Italian, Latin and Greek were once dialects of the Indo-European language family with a common ancestor and semantic interpretation. Sardine refers to the specie of small fishes, smaller and rounder than herrings, found in great numbers along the coasts of Europe. In Cameroon English speech, it describes a group of Cameroonian migrant students in the diaspora, who gather together and congested in a single small room or space, the way sardine is canned. From the corpus, the word Sardinards is a description of someone in this specified condition. The new form Brigarde Anti-Sardinards refers to a group of followers and fervent supporters of the regime in place and its leadership, while the Tontinards, designates the group of supporters of a leading opposition leader of the renaissance movement. This social practice exists with Africans in the diaspora, where people of particular tribe meet regularly and today, its designation is extrapolated to political tribalism described by some as une proximité sociologique. ${ }^{9}$

In the political scene, a majority of the so-called Sardinards are described as a group of over-zealous hooligans of a specific speech community. Note that the

9 For more, see Le Debriefing de l'Actu' on Equinox TV of 13/05/2020 commenting on Alain Foka (RFI) Affair, when Charles Atangana Manda, Director of the 'Observatoire des médias et de l' Opinion Public' at the Ministry of Communication used the expression 'une proximité sociologique' as an index of tribal politics. 
utterances and words we use are symbols by which we express our ideas and cultural identity. The vocabulary system of a language is a reflection of the political and social realities of that society. In contemporary English speech, these expressions are used to stigmatize persons or a group of persons from particular ethnic groups when they do not share similar political ideologies or social habits and practices. Note that the word anglo, is derived from Indo-European family (Angles, Anglia) from which 'anglais' is French and not English. These speakers hold an incorrect view or belief of someone or something. New words such as these mentioned above have entered Contemporary English at the time when so many young people in the diaspora have lived traumatizing experiences in Europe. Speakers who have lived in the Far north region or have been following the war in the Northwest and Southwest regions of Cameroon are familiar with words like boko haram, Amchide, and terrorism. As well as ambazonia, NOSO, ambaboys, separatists, General peaceplant, secessionists, General Tiger, General deadman, and General Obi are the variety of neologisms derived from different real events such as terrorism by the Islamic Boko Haram insurgent in Kolofata and Amchide villages, the Anglophone crises with the Ambazonia restoration autodefense operational militia forces made up ambaboys in the different parts of the two English-speaking Northwest and Southwest regions and styled separatists commonly used and accepted in Cameroon English speech as normal. Their specific meanings are related to the military exploits and experiences in the Anglophone crises. These expressions provide glaring examples of familiar words serving to create other new words and take on new meanings within specific contexts. The adjectival form 'general' describing the high official grade in the military is a familiar word, like Peaceplant, called the Nkeng in Limbum (a symbol of peace and believed to possess the elixir of peace whenever it is held in African traditional communities), similar to the word Tiger (a ferocious animal of the feline family), and deadman (a description of his mission to kill), and Seven Katta, ${ }^{10}$ have been existing, but are now part of everyday Cameroon English speech with new meanings. The word ambaboys, succinctly describes the quality of the auto-defense force of ambazonia militia-boys of Ambazonia restoration fighters engaged in the secessionist war in terms of age range and youthfulness. It becomes clear when we encounter other new words mentioned above as different self-appointed General Death depending of his mission and location, or a selfappointed field marshal in charge of military operations. The expression Red Dragons is reminiscent of the Vietnamese operational forces and borrowed to describe a particular militia force operating in the Lebielem county. Other typical compound loans found in the data include; Kamtomisine, Kondenguise, Ambaboys, Saddle Hill Ranch, and county.' These utterances and others have become popular in use and acceptable as English speech derived from a variety of sources and different aspects of life as people, plants, animals,

10 The expression, 'Seven Katta' is a derogatory form to refer to Bafut people. place names and military titles etc., commonly heard in Cameroon English, but which tend to take on new forms with different meanings. These utterances express old ideas in new ways especially those intimately associated with the military operations in the restoration war.

\subsection{Self-explaining Compounds}

Another technique used in forming new words in Cameroon English is self-explaining compounds is a common practice speakers use to form new words. This technique requires the speaker to draw from his intuitive knowledge of English grammatical structures of derivative morphology. 'Compounding' is the process of combining two or more free morphological elements to form whole new words. This may consist of noun-noun compounding, for example, peace-plant, Kamto-mania, enthno-fascism, corona-virus, Rue-public, seven-katta, amba-boys, faidom, shufaidom, photo-cracy, etc. Note that the word phone in the following examples signify a speaker of; Anglo-phone, Bassa-phone, Duala-phone, fufuldophone have become commonplace compounds composed of tele and phone, or Luso to obtain telephone, micro-phone, mega-phone. An 'anglo-phone' is someone who speaks English, and a Bassa-phone is someone who speaks Bassa. Equally, a lusophone is a Portuguese speaker. The word phone signifies sound transmission perhaps through electrical signals over distances telephone and as received signals through sounds. In the corpus, compounds as come-no-go, antirepublican, (against the republic) or anti-sardinards (against the Sardinards), anti- signifies 'against, opposite' carry the negative marker 'no' and 'anti- ' to signify against Sardinard or the republic, or against an idea. Other self-explaining compounds including Kamtomania, gourou-tonton Maurika, designating the opposition leader Pr. Maurice Kamto, are derived from the most active political figure in Cameroon. Self-explaining compounds betray their newness in the language by being written with a hyphen or as separate words, or sometimes, by preserving a very strong accent on each element. In a similar way, the lists of native words are derived in answer to the need to localize and identify their sources and express ideas so intimately associated with the objective and existing concepts. The expression Saddle Hill Ranch, is selfexplanatory and context bound with such words as 'saddle' and 'hill' are appropriate descriptions of the north-west environment made up a hilly and mountainous landscape appropriate for cattle grazing due to its rich hill pasture good cattle rearing ranch. A saddle is a seat for the rider of a horse or other animals. Of course, not only do we find cattle in a ranch, but also horses. The structure Saddle Hill Ranch is borrowed from the English language and used to name a place in the speaker's immediate northwest locality however with the feeling that this zone resembles the saddle hill he is familiar with elsewhere. Creating self-explanatory expressions of this nature are a prominent feature in Old English, which continue to remain valid with contemporary English.

Cultural differences are probably more startling sources of deriving new words with new meanings, e.g., the suffix 'cracy', describe different forms of political regimes, as 
democracy, bureaucracy, gerontocracy, autocracy structurally similar to photocracy from photo and -cracy, directly related to imaging, thus photocracy is a new word that has entered Cameroon English corpus and is now a familiar word to designate a culture or system of governance by placing the photograph of the president. A 'photo', the short form for photograph describes an image or picture, and the suffix '-cracy' denotes rule or system of governance as democracy. Photocracy designates a system of government by placing the photograph of the president to rule in silence or long absence of the person in answer to a pressing political situation of the president's absence. Notice that photocracy expresses a new idea or doctrine intimately associated with the photograph replacing a supposed absence of the president at a time when his presence is highly needed. The term photocracy, has become a descriptive linguistic reality employed to fill a vacuum, usually of a meta-linguistic nature.

\subsection{Acronyms}

An acronym is a type of abbreviation formed from the initial letters of a set of words. In order to form new words, speakers tend to imagine appropriate expressions from current situations to fit their ideas, as in BAS (Brigade AntiSardinards), 1Xbet, or hooligan Tontinards ${ }^{11}$ They are pronounced as new single words. Examples: NOSO for Northwest and Southwest, $3 D$ for three dimension, $5 \mathrm{G}$ for the fifth generation, $M T N$ for Mobil Telephone Network, COVID-19 for Coronavirus disease nineteen, $C D$ for Compact Disc, @ for at, G-Zero for Ground zero; The word COVID-19, Elixir covid, are not quite new words in English, but are words that have taken different meaning dimensions in contemporary English, and have entered contemporary English signifying the specific virus also described as SARSVIRUS similar to UNICEF (The United Nations Educational Children's Fund). Within conventional and traditional medicine, the 'coronavirus, COVID-19 is a recent global pandemic that has witnessed the introduction of several new words into the vocabulary of Cameroon English. The word corona Latin corōna (garland, crown), from Ancient Greek (korōnē, garland, wreath") is not new in botany, as a trumpetlike shaped or cup-like shaped outgrowth of the corolla of a daffodil or narcissus flower.

\subsection{Neologism}

Neologism is considered the act of inventing a new word or phrase, combining familiar words in new ways to obtain a new form as Maurika, for Maurice Kamto. Referring to sections of the Kondengui central prison as Kosovo and Quantanamo, are old words borrowed and applied to new contexts from famous American detention camps for political prisoners that 0today have become normalized and accepted in the mainstream English speech. République, is derived from Latin 'rēs publica' ("republic"), and also from rēs ("thing") + püblica ("public");

11. For more, François Gaël Mbala (Stagiaire) quotes Pr. Mathias Eric Owona Nguini: in http//www./com/societe/ 1106606/lebledparle.com., Wednesday 3rd April, 2019 at 1:00 p.m. literally based on the concept of the 'public' or people being at the centre of governance as a "public thing." Originally, Republicanism is a political system of governance in which supreme power is vested in the president and a body of elected representatives and institutions governed through the rule of the law. However, a new word has been created in Cameroon, ruepublic with the perpetual protests and human rights abuses experienced in Cameroon, the citizens tend to spend more of their time in the streets, giving rise to the word ruepublic to describe a situation where the rule of the law is rather in the public streets with protesters as observed elsewhere in Algeria, Tunisia. Members of Cameroon People's Party (CPP) devised the concept of 'Black Friday, to pressurize the government to put an end to the crises, and similarly, members of the Cameroon Renaissance Movement also organized the la marche blanche, ${ }^{12}$ a concept of hold-up victory, CAN hold-up, etc. This kind of coinage is often an analogy with some other word or words consciously or unconsciously associated with achieving desirable goals in the community.

\subsection{Eponym}

Eponymy is the process in which a word is derived from the name of a person (real or imaginary), for whom something is named after him or her. The corpus contains several samples of such new words as Biyaistes, to describe supporters of H. E. Paul Biya, president of the Republic of Cameroon, Gargarism, from Garga Haman; Kamtomania, Kamtomisine, Kamtogate, neokamtoistes, Kamtoism, Maurika, formed from Maurice Kamto, the names of prominent political leaders; Deidogate from scandals in Deido; Kledavid, is a new anti-Covid19 manufactured by a cleric Bishop Kleda, are some expressions derived from names of prominent political leaders in Cameroon. Slightly different, the expression Cameroon's Macron refers to Hon. Cabral Liibi Gue, who so far, is the youngest opposition leader of (PRCN) party as young as Emmanuel Macron, president of France. Note that these particles -ism, -mania, ards, are added to the root to form abstract concepts as in Kamtoism, enthnofascism, or -mania as in Kamtomania, Feymania, megalomania; -ise in Kondenguise used to form verbs from nouns or adjectives, the verbs having the sense of "to make what is denoted by the noun or adjective as -ard denotes someone who is in a specified condition as in Tontinards, Sardinards, which are completely new forms introduced into contemporary Cameroon English and commonly encountered. Note that the suffix -ism (belief), is used to form noun classes of an action or process as in capitalism, Republicanism, liberalism, ethnofascism, particularly in the 19th century to describe familiar political systems and beliefs of "social movement", accepted as authoritative by doctrine and school of thought. The suffix ' $d o m$ ' is a short form for dominator, exercise of power (in

12. 'La Marche blanche' describes the protest campaign organized by members of the CRM of 26 January 2019, at the national and international levels (Douala, Yaounde, West, Paris, Berlin, Canada, etc.) to say 'No to Hold-up CAN' and a restitution of the supposed stolen election victory. 
sadomasochistic sexual practices), especially from a male partner, commonly found in chiefdom, kingdom, faidom, shufaidom, to describe local administration where 'dom signifies the area or place where the king or chief, or Fai dominates and is in control. These forms are derived as a result of different grammatical inflexions, prefixes and suffixes to existing structures to derive new ones. Several Latin prefixes lend themselves readily to new combinations. These processes of affixation have enriched the vocabulary of Cameroon English.

\subsection{Nominal Clausal Structures}

A combination of the adjective and nominal clausal structure is another technique speaker's use to enrich Cameroon English vocabulary. Expressions from political discourse such as les chants trompeurs, des marchands d' illusions, ${ }^{13}$ les Vendeurs des illusions, and les oiseaux des mauvaises augures, un petit glissement des dates, from French are considered vain deceitful talk that signify opinions and attitudes of political actors who promise empty and illusory projects to the population. In the same light, expressions as une dictature sanguine, les analphabètes politiques, les apprentis sorciers and Les piètres politiciens, designate inexperienced political actors who want to venture in the Cameroon political arena. A sociopragmatic approach of this sort identifies and exposes the ways in which political ideology and language use are constantly instantiated and enacted in the familiar discourse of the of everyday interactions through different media.

\section{Contemporary Cameroon English Speech}

The value of Cameroon English, to a greater extent, depends on the importance of the people who speak it and the purpose for which they use it. Cameroon English is a variety of language characteristic of contemporary speech used and acceptable as normal within Cameroon irrespective of provenance and education status. The Cameroon multi-media has played a preponderant role in informing, educating and entertaining the people and most importantly influencing the way Cameroonians see, think and talk about their daily political activities, social life, traditional medicines, the military, and culture. Neologism has greatly influenced the development of new words that have enriched contemporary Cameroon English. The social media has equally contributed to foster the creation of new utterances to express new concepts; they further promote, diffuse and spread new words within the community. It is the result of a mixture of French, English, Cameroon Pidgin English, 'Camfranglais', local languages co-existing in Cameroon within the three main lingua franca zones within Cameroon: the Fulfulde lingua franca zones in the north, the Pidgin English lingua franca zone in the west and the French lingua franca zone in the rest of the country. 'Camfranglais' is inevitable. Cameroon English

13 For more on this speech, see President Paul Biya, on Twitter, 03 May 2019. speech has taken a national dimension; used in newspapers, radio broadcast, television programmes, political rallies and campaigns, in the secondary school and university milieu, churches, markets, motor parks, railway stations, music, films, literature, as well as in many other formal and informal situations. Not only does the speech of one community differ from that of another, but the speech of different individuals of a single community, even different members of the same family, is marked by individual peculiarities. If culture describes all the native speaker's intuition about the knowledge and the values shared by members of this society, it exposes the linguistic processes, attitudes and social behavior characteristic of Cameroon. Thus, Cameroon English neologism above is a mixture of foreign, dialectal and cultural borrowings, coinages, eponyms, derivations, self-explaining compounds as observed within Cameroon. The more we know about a particular society, the more effectively we can communicate in it. Gumperz (1964) [27].

\section{Conclusion}

The study, which set out to examine neologism and the media in Cameroon English, has described coined utterances, words and expressions, most of which are frequently used and have been accepted as contemporary Cameroon English. It was noticed that language users tend to sort out the semantic categories provided by their respective codes that distinguish different experiences lived by the population. It further demonstrates that the resources available and the existing linguistic codes are understandably inexhaustible from a sociopragmatic perspective. Thus, the generic semantic meanings of these codes have been established over a considerable period of time within complex Cameroon speech community.

When different languages come into contact, they share similar grammatical structures and lexical features with other co-existing languages, and make it easier for its speakers to express their ideas. Rather than just combine existing elements to form new words, as in German, contemporary Cameroon English has shown a marked tendency to go outside her own linguistic resources and borrow from other languages. Knowledge of language is acquired by such mechanisms as conditioning, association, and neologism is the practice in exercising these language skills, etc. Findings from this study have revealed that the Cameroon media plays a preponderant role in creating and promoting neologisms in contemporary Cameroon English which cannot be underestimated. In effect, contemporary Cameroon English is a mixture of substandard indigenized English, cosmopolitan French, Cameroon Pidgin English, Camfranglais and other local languages spoken in Cameroon.

Contemporary English neologism, to a greater extent, emanates within the particular dramatic socio-political crises and experiences encountered by Cameroonians, which has affected and inspired language users. Notice the influence of democracy, including freedom of speech and technological developments on linguistic behaviour. Language as a code is not only a mirror of the mind, but it reflects cultural preoccupations and constraints of the way people think. We 
are then, not prisoners of the cultural meanings offered to us by our language, but man is a co-creator of new words to enrich the vocabulary system of any language from a sociopragmatic reading.

In conclusion, language influences our perceptions, thought, and, at least potentially, our linguistic behavior in a way that neologism is not only a dynamic process by which contemporary Cameroon English vocabulary has developed, but a means to understand the sociopolitical life of a people and their rich culture as part of the global social system.

\section{References}

[1] Widdowson H. G (1979). "Rules and Procedures in Discourse Analysis", in T. Myers (ed.), The Development of Conversation and Discourse. Edinburgh: Edinburgh University, University press.

[2] Breton, Roland and Fohtung, Bikia (1991): Atlas administratif des langues nationales du Cameroun, Yaoundé, Paris.

[3] Wolf, Hans-Georg (2001): English in Cameroon. Berlin/New York.

[4] Boum Ndongo-Semengue, M. A./Sadembouo, Etienne (1999): "L'Atlas linguistique du Cameroun: les langues nationales et leur gestion," In Mendo Ze, Gervais (ed.): Le français langue africaine: enjeux et atouts pour la Francophonie.

[5] Ethnologue (2002) Languages of the World; Cameroon, published by the Summer Institute of Linguistics (SIL) International, www.ethnologue.com.

[6] Mendo Ze, Gervais (ed.) (1999): Le français langue africaine: Enjeux et atouts pour la Francophonie. Paris.

[7] Bot Ba Njok, Henri Marcel (1966): "Le problème linguistique au Cameroun". L'Afrique et l'Asie No. 73: 3-13.

[8] Ngo Bitja'a Kody, Zachée Denis (1999): "Problématique de la cohabitation des Langues". In: Mendo Ze, Gervais (éd.): Le français langue africaine: Enjeux et atouts pour la Francophonie. Paris: 80-95.

[9] Biloa, Edmond (1999): "Bilingual Education in the University of Yaounde I: The Teaching of French to English Speaking Students" in Echu, George/Grundstrom, Allan W. (eds.): Bilinguisme officiel et communication linguistique au Cameroun. New York: 53-74.

[10] Chumbow, Sammy Beban (1996): "The Role of National Languages within a Comprehensive Language Policy for Cameroon". Academic Discourse presented at the University of Buea.
[11] Mbangwana P, Mpoche K., Mbuh T., (eds.) (2006), Language, Literature and Identity, CUVILLIER VERLAG, Gottingen.

[12] Mushing W. T. (2007), "The Spoken Language of the Wimbum Ruling Class, A Study in Discourse Structure and Function", A Ph. D. thesis defended at the Department of English, FALSS, University of Yaounde 1, Cameroon.

[13] Chomsky, Noam (1957). Syntactic Structure. The Hague: Mouton. ISBN 3-11-017279-8.

[14] Chomsky, Noam (2012) with James McGilvray; The Science of Language, Cambridge University Press.

[15] Holmes, J. (2001) International Encyclopedia of the Social \& Behavioral Sciences.

[16] Pennycook A. D (2016), Critical Approaches to English Language Teaching, Shangai Foreign Language Education Press, Shangai.

[17] Carroll, J. B et al. (2012), Language, Thought, and Reality: Selected Writings of Benjamin Lee Whorf, Second Edition, the MIT Press.

[18] Saville-Troike, M (2003) The Ethnography of Communication: An Introduction ( $3^{\text {rd }}$ ed.) Blackwell Publishing, UK.

[19] Hilbert, Richard, (1992), The Classical Roots of Ethnomethodology; Durkheim, Weber, and Garfinkel, p. 13, Chapel Hill, NC; The University of North Carolina Press.

[20] Ritzer, George (2011) "Ethnomethodology." Pp. 301-415 in Sociological Theory, $8^{\text {th }}$ Ed. New York, NY, McGraw Hill.

[21] Garfinkel H. (2017) published in Jacobson, Micheal Hviid; The Interactionist Imagination studying Meaning, Situation and Micro-Social Order, London, Palgrave-Macmillian, PP. 233-261.

[22] Skinner B. F. (1957) Verbal Behaviour Appleton Century, New York, USA.

[23] Todd J. T. and Morris E. K. (1995) in Modern Perspectives of John B Watson and Classical Behaviourism, ed. Todd and Morris, Greenwood Press.

[24] Grice H. P. (1989) Studies in the Way of Words. Harvard University Press, 385 pp., Volume 65 Issue 251.

[25] Austin J. L (1962) How to do Things with Words, Oxford University Press, Oxford.

[26] Leech, G. N. (1983), Principles of Pragmatics, London, England, Longman, p. 11.

[27] Gumperz John J. and Jenny Cook-Gumperz, (2008) "Studying language, culture, and society: Sociolinguistics or linguistic anthropology"? Journal of Sociolinguistics 12 (4), 2008: 532545 . 